удк 330.34:316.42

\title{
ВИКОРИСТАННЯ GREEN FINTECH У РОЗВИТКУ СОЦІАЛЬНО-ВІДПОВІДАЛЬНОГО БІЗНЕСУ ${ }^{1}$ \\ GREEN FINTECH IN THE DEVELOPMENT OF SOCIALLY RESPONSIBLE BUSINESS
}

\author{
Пахненко Олена Михайлівна \\ кандидат економічних наук, доцент, \\ Сумський державний університет \\ ORCID: https://orcid.org/0000-0002-4703-4078 \\ Коломієць Поліна Юріївна \\ студент, \\ Сумський державний університет \\ ORCID: https://orcid.org/0000-0002-7313-2835
Pakhnenko Olena, Kolomiets Polina
Sumy State University

\begin{abstract}
У статті проведено аналіз розвитку Green FinTech у світі, визначена його роль у досягненні цілей сталого розвитку та запропонована класифікація основних його напрямків, а саме: 1) використання FinTech у іміджевих та благодійних еко-проєктах; 2) FinTech-рішення у «зеленому» інвестуванні; 3) індраструктурні проєкти та управління Green FinTech. Критерієм віднесення до першого напрямку обрано відсутність прямої фрінансової винагороди для інвестора (донора) і спрямованість на досягнення позитивних екологічних есректів; до другого напрямку - спрямування коштів у проєкти, що відповідають цілям сталого розвитку, та забезпечення прибутковості для інвестора; до третього напрямку - використання FinTech рішень та технологій (онлайн платорорми, блокчейн, штучний інтелект тощо) для фрормування «зеленої» фрінансової інфраструктури.
\end{abstract}

Ключові слова: зелені інновації, зелені інвестиції, соціально-відповідальний бізнес, ФінТех, сталий розвиток.

В статье проведен анализ развития Green FinTech в мире, определена его роль в достижении целей устойчивого развития и предложена классификация основных его направлений, а именно: 1) использование FinTech в имиджевых и благотворительных эко-проектах; 2) FinTech-решения в «зеленом» инвестировании; 3) инфраструктурные проекты и управление Green Fintech. Критерием отнесения к первому направлению является отсутствие прямого фринансового вознаграждения для инвестора (донора) и направленность на достижение положительных экологических эффректов; ко второму направлению - предоставление средств на проекты, отвечающие целям устойчивого развития, и обеспечение прибыльности для инвестора; к третьему направлению - использование FinTech решений и технологий (онлайн платформы, блокчейн, искусственный интеллект и т.п.) для формирования «зеленой» фринансовой инфраструктуры.

Ключевые слова: зеленые инновации, зеленые инвестиции, социально-ответственный бизнес, ФинТех, устойчивое развитие.

The article analyzes the global development of Green FinTech, identifies its role in achieving sustainable development goals and proposes a classification of its main areas, namely: 1) the use of FinTech in image and charitable eco-projects; 2) FinTech solutions in green investing; 3) infrastructure projects and management of Green FinTech. The first area of Green FinTech is characterized by the absence of a direct financial reward for the investor (donor) and is aimed at achieving positive environmental effects in the form of reducing carbon dioxide emissions, decreasing the use of plastic, increasing green space on the planet and more. The goals of this area are achieved by financial intermediaries and FinTech companies using various tools: contribution of a fraction of companies' revenues to fund frontier carbon removal technologies (e.g., Stripe), wooden debit cards (e.g., TreeCard), rounding of transaction amounts and transfer of the difference to the financing of tree planting (e.g., Aspiration Zero).

${ }^{1}$ Виконано в рамках науково-дослідної теми «Зелене інвестування: коінтеграційна модель трансмісійних ESGефектів у ланцюзі «зелений бренд України - соціальна відповідальність бізнесу» (№ д/p 0121U100468), що фрінансується за рахунок коштів державного бюджету. 
The second area (green investing) aims to make a profit for the investor, but the choice of projects is based on their compliance with sustainable development goals. Investor involvement in green investing based on FinTech can vary from providing funds (e.g., Atmos) to self-selecting of investment projects (e.g., Raise Green, Trine). The third area includes FinTech solutions and technologies used to create a green digital financial infrastructure: online platforms (microgrid peer-to-peer energy platforms, e.g., Vandebron, Piclo; online platforms for facilitating renewable energy transactions, e.g., Blueyellow), blockchain, artificial intelligence, etc. (Treelion, Doconomy). The flexibility and adaptability of the FinTech segment allows to extend successful technological developments to other areas. FinTech demonstrates significant potential in terms of its application in green finance and socially responsible business. The results of practical application of Green FinTech show its importance in building an ecological model of the economy based on sustainable development.

Keywords: green innovations, green investments, socially responsible business, FinTech, sustainable development.

Постановка проблеми. До недавніх пір поняття «FinTech» було новинкою як з точки зору теоретичного обґрунтування у науковій літературі, так і щодо практичних аспектів адаптації сучасних інформаційних технологій у фрінансовій сорері. Однак стрімкий розвиток процесів цисрровізації і пов'язаної із нею транссрормації суспільства забезпечив умови не лише для швидкої адаптації існуючих FinTech-інновацій, але i для формування на їх підґрунті нових напрямків і різновидів, що задовольняють більш конкретні цілі і потреби споживчого ринку. Зокрема, зважаючи на те, що одним із основних орієнтирів сучасного розвитку суспільства $€$ формування соціально-відповідальних моделей ведення бізнесу та досягнення позитивних ефектів за ESG-критерієм, цілком обґрунтованим $€$ пошук можливостей для досягнення цих цілей і у FinTech-сегменті та виокремлення відповідної категорії FinTech-послуг та FinTech-інновацій як «Green FinTech».

Аналіз останніх досліджень і публікацій. В цілому питання, пов'язані із розвитком Green FinTech, враховуючи новизну цього явища, $\epsilon$ недостатньо розробленими як у вітчизняній, так і зарубіжній літературі. Поряд із тим, такі суміжні 3 Green FinTech напрямки як «зелені» фрінанси або FinTech-інновації $€$ предметом дослідження багатьох науковців. Зокрема, варто відзначити роботи в цій галузі таких вітчизняних дослідників, як М. Карлін, К. Маркевич, Т. Пімоненко, Л. Рибіна, А. Семеног, О. Чигрин, Н. Андрєєва та інших. Серед іноземних науковців зазначені питання вивчають: Д. Насcipi [3], Т. Пушман [4], Дж. Сакс, П. Мартін, Г. Індерст, Л. Абрахам, Л. Ейро та інші.

Мета статті полягає в аналізі напрямів розвитку Green FinTech у світі, проведенні їх систематизації та визначенні їх ролі у досягненні цілей сталого розвитку.

Виклад основного матеріалу. Узагальнення наявних практичних кейсів поєднання елементів соціально-відповідального бізнесу та інновацій у copepi FinTech дозволило виокремити три осно- вних напрямки сучасного розвитку Green FinTech у світі: використання FinTech у іміджевих та благодійних еко-проєктах; FinTech рішення у «зеленому» інвестуванні; інсрраструктурні проєкти та управління Green FinTech (рис. 1).

Перший напрямок Green FinTech характеризується відсутністю прямої фрінансової винагороди для інвестора (донора) і спрямований на досягнення позитивних екологічних ефректів у вигляді зниження викидів діоксиду вуглецю, зменшення використання пластику, збільшення зелених насаджень на планеті тощо. Реалізація цілей даного напрямку може досягатися фрінансовими посередниками та FinTech-компаніями із застосуванням різних інструментів. Наприклад, американська технологічна компанія «Stripe», яка надає широкий спектр послуг у ссрері прийому і обробки електронних платежів, пропонує своїм корпоративним клієнтам здійснювати автоматичні відрахування певної частки їх доходу (відповідно до попередньо встановленого відсотка відрахувань) на фрінансування передових технологій щодо зменшення вуглецевих викидів. Компанії, які здійснюють відрахування, отримують спеціальний зелений значок, який може використовуватися для фрормування позитивного іміджу компанії [6].

Іншим прикладом $\epsilon$ використання дерев'яних платіжних карток, як це робить німецька компанія «Ecosia», що інвестувала 1 млн фрунтів стерлінгів у британський FinTech-стартап «TreeCard» [9]. Дерев'яні платіжні картки виконують усі фрункції традиційних дебетових карток. Однак, на відміну від останніх, вони виготовлені виключно із органічних і перероблених матеріалів, а комісійна винагорода за їх використання спрямовується на фрінансування висадки дерев у 15 різних країнах. При цьому комісійна винагорода знімається не з користувача, а 3 продавця або магазину, в якому оплачуються покупки. Користувачі таких карток можуть відстежувати свої витрати і бачити, висадку скількох дерев вони профрінансували. 


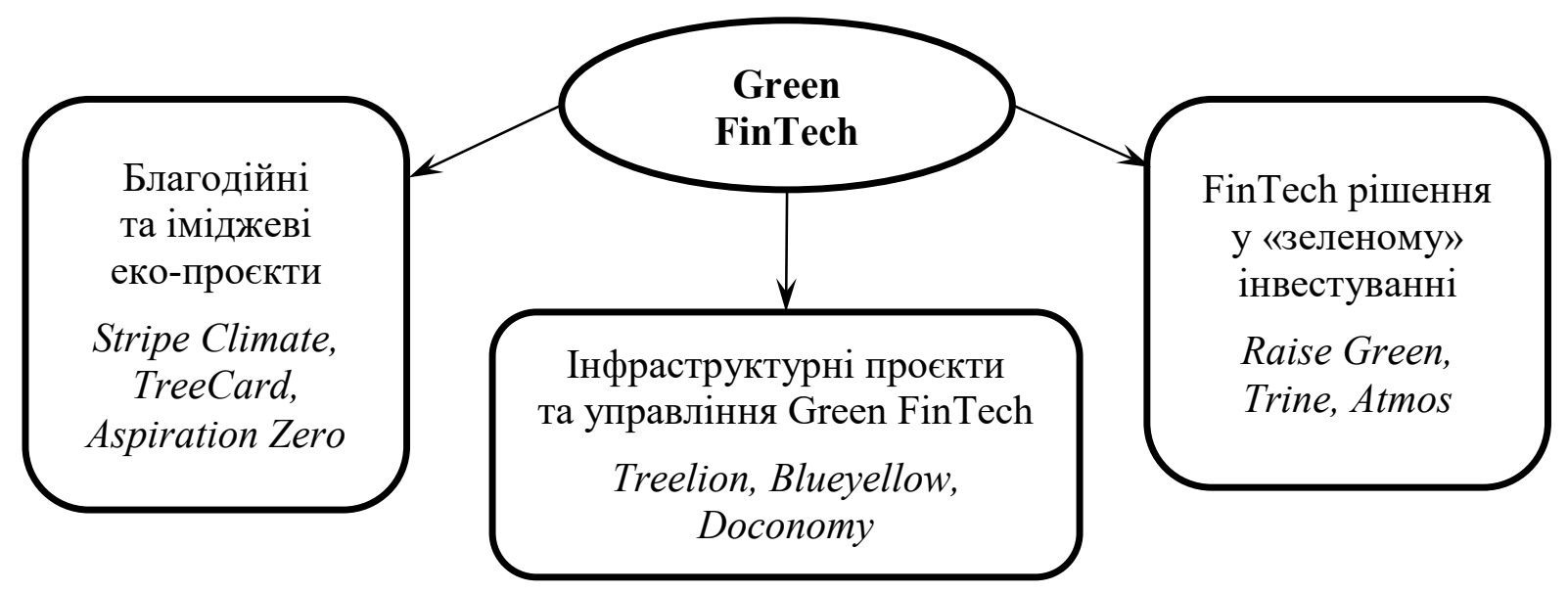

Рис. 1. Основні напрями сучасного розвитку Green FinTech

Джерело: сформовано авторами

Схожу мету переслідує і компанія «Aspiration», яка у 2020 році запровадила фрункцію «Plant Your Change» для поточних рахунків клієнтів, що полягає в округленні суми будь-якої транзакції до найближчого долара і перерахуванні відповідної різниці на фрінансування висадки дерев. У 2021 році компанія почала випускати платіжні картки «Aspiration Zero», які за рахунок відрахувань 3 кожної покупки дозволяють їх власникам компенсувати свій вуглецевий слід, а також отримувати кешбеки при досягненні цільової суми щомісячних відрахувань [12].

Наступним важливим напрямком розвитку Green FinTech $€$ використання інноваційних срінансових технологій у зеленому інвестуванні. На відміну від благодійних та іміджевих еко-проєктів, зелене інвестування має на меті отримання інвестором прибутку, однак вибір проєктів здійснюється з урахуванням їх відповідності цілям сталого розвитку. Зелене інвестування на основі FinTech може передбачати різну ступінь участі кінцевого інвестора у виборі проєкта. Наприклад, компанія «Atmos» сорормувала інноваційну модель кліматично сприятливого банківського обслуговування. Співпрацюючи із різними фрінансовими установами, «Atmos» акумулює кошти на депозитних рахунках та спрямовує їх в інвестиції виключно в кліматично-позитивну інорраструктуру 3 метою прискорення переходу до чистої, справедливої та трансфрормованої економіки. Зокрема, пріоритетними напрямками інвестування «Atmos» визначають відновлювані джерела енергії, проєкти 3 підвищення енергоефрективності, електричний транспорт, зелене будівництво та відновне сільське господарство [8].
Альтернативним варіантом, що передбачає активну участь інвестора у виборі об'єктів зеленого інвестування, є створення спеціалізованих інвестиційних платфрорм для розміщення проєктів 3 енергоесрективності, відновної енергії тощо, за прикладом фуункціонування краудфандингових та peerto-peer онлайн-платфрорм. Суттєвою перевагою такого підходу є можливість перенесення орінансування відповідного рівня проєктів на регіональний або місцевий рівень, а також збільшення кількості залучених інвесторів, у тому числі 3 місцевої громади, без одночасного нарощення транзаційних витрат. За принципом онлайн-платформ функціонують такі Green FinTech компанії як «Trine» та «Raise Green».

Компанія «Trine» спеціалізується на інвестиціях в сонячну електроенергію. Алгоритм участі в зеленому інвестуванні 3 використанням платформи «Trine» досить простий і включає: попередню реєстрацію на сайті; вибір об'єкта інвестування серед запропонованих варіантів 3 урахуванням локації, розмірів, ризиків та інших параметрів; визначення обсягу інвестиції (мінімум 25 євро). При успішному завершенні проєкту інвестор отримує винагороду у вигляді відсотків [10].

Схожий підхід застосовується і у функціонуванні платсрорми «Raise Green», створеної як ліцензований фрінансовий портал Комісії 3 цінних паперів і бірж (SEC) та Регулюючого органу фрінансової індустрії (FINRA) у США. Через платорорму «Raise Green» можна знайти та інвестувати у будь-який локальний еко-проєкт. Учасниками платорорми можуть бути як акредитовані, так і неакредитовані, індивідуальні та інституційні інвестори. Окрім 
безпосередньо фрінансової інфрормації про інвестиції платформа дозволяє показувати очікувані наслідки від інвестицій, зокрема обсяги кіловат-годин чистої енергії, які створено за рахунок внеску кожного інвестора [5].

Принцип онлайн-платформ активно використовується і в іншому напрямку розвитку Green FinTech, зокрема в інсрраструктурних проєктах та управлінні. По прикладу краудфрандингових платформ можливе створення локальних маркетплейсів для надання i отримання енергії. У свою чергу, для зниження енергоспоживання та орормування мереж більш ефективного розподілу енергії між користувачами платорорми, використовуються технології штучного інтелекту.

Технології Green FinTech дозволяють учасникам купувати та продавати енергію на роздрібних або оптових ринках на умовах рівноправного доступу та орієнтованих на громаду енергетичних систем, таких як мікромережі. Користувачі мікромереж можуть обирати, звідки хочуть отримувати енергію. Цей підхід вже має декілька прикладів успішного застосування у світі: платорорма Vandebron Energy у Нідерландах, платорорма Piclo у Великобританії, ринок однорангових енергетичних транзакцій в мікромережах у Брукліні (НьюЙорк, США). Функціонують також онлайнплатсрорми, які опосередковують транзакції з відновлюваною енергією, прикладом яких $€$ швейцарська платорорма Blueyellow [7].

Слід також звернути увагу на інфрраструктурні проєкти, які мають більш широку спрямованість і сприяють розвитку різних видів Green FinTech продуктів. Наприклад, фронд «Treelion», який був створений у 2019 році, на сьогоднішній день реалізує проєкти в понад 30 країн і регіонах світу загальною вартістю більше 1 млрд доларів. Основна мета діяльності фонду - це створення «зеленої» цифррової фрінансової інфрраструктури на основі технології блокчейн. Стратегічними орієнти- рами діяльності Фонду є: вирішення проблем забруднення землі, повітря, ґрунту та біологічного забруднення для сприяння будівництву екологічної цивілізації; підтримка сталого і «зеленого» бізнесу завдяки поєднанню екології, фрінансів та цифррових технологій, створення найбільшої «зеленої» екосистеми цифрових даних; ведення бази даних про глобальне навколишнє середовище та біологічне різноманіття із застосуванням технології блокчейн; сприяння екологічному співробітництву на міжнародному, регіональному, національному та місцевому рівнях, створення екологічної цивілізації [11].

Іншим прикладом $€$ шведський стартап «Doconomy», діяльність якого орієнтована на створення екосистеми орінансових інструментів для навчання та стимулювання позитивних змін. Doconomy співпрацює з фрінським банком «Ålandsbanken», $\mathrm{OOH}$ та MasterCard для підвищення глобальної обізнаності про проблеми зміни клімату, використовуючи для цього можливості міжнародного банкінгу та глобальних технологій платежів [2].

Висновки. Сучасний розвиток FinTechсегменту забезпечує ринок фрінансових послуг інноваційними рішеннями, сприяючи підвищенню ефрективності його фрункціонування, а гнучкість та адаптивність FinTech-сегменту дозволяє поширювати вдалі технологічні розробки на інші сорери суспільного життя. FinTech демонструє значний потенціал щодо можливостей його застосування у «зелених» фрінансах та соціально-відповідальному бізнесі. Наявні на сьогоднішній день результати практичного застосування FinTech у іміджевих та благодійних еко-проєктах, «зеленому» інвестуванні та при фрормуванні «зеленої» цифррової інсрраструктури засвідчують перспективність цього напрямку і можливість використання Green FinTech для побудови екологічної моделі економіки на основі сталого розвитку.

\section{СПИСОК ВИКОРИСТАНИХ ДЖЕРЕЛ:}

1. Building Block(chain)s for a Better Planet. World Economic Forum. September 2018. URL: https://www3.weforum.org/docs/WEF_Building-Blockchains.pdf

2. Doconomy. URL: https://doconomy.com/

3. Nassiry D. The Role of Fintech in Unlocking Green Finance: Policy Insights for Developing Countries. ADBI Working Paper Series. 2019. No. 883. URL: https://www.adb.org/sites/default/files/publication/464821/adbi-wp883.pdf 4. Puschmann T., Hoffmann C.H., Khmarskyi V. How Green FinTech Can Alleviate the Impact of Climate Change The Case of Switzerland. Sustainability. 2020. № 12(24). 10691. DOI: https://doi.org/10.3390/su122410691

5. Real Change Starts With You. Raise Green. URL: https://www.raisegreen.com/

6. Remove carbon as you grow your business. Stripe Climate. URL: https://stripe.com/en-pl/climate

7. Renewable energy transactions are going digital. Blueyellow. URL: https://www.blueyellow.com/ 
8. Smarter banking reverses global warming. Atmos Financial. URL: https://www.joinatmos.com/

9. TreeCard. URL: https://www.treecard.org/

10. Trine. URL: https://trine.com/

11. Treelion beyond Gren. URL: https://treelion.com/index_en.html

12. You can change Climate Change. Aspiration. URL: https://www.aspiration.com/

\section{REFERENCES:}

1. World Economic Forum (2018) Building Block(chain)s for a Better Planet. Available at: https://www3.weforum.org/ docs/WEF_Building-Blockchains.pdf

2. Doconomy. Available at: https://doconomy.com/

3. Nassiry D. (2019) The Role of Fintech in Unlocking Green Finance: Policy Insights for Developing Countries. ADBI Working Paper Series, no. 883. Available at: https://www.adb.org/sites/default/files/publication/464821/adbi-wp883.pdf

4. Puschmann T., Hoffmann C.H., Khmarskyi V. (2020) How Green FinTech Can Alleviate the Impact of Climate Change - The Case of Switzerland. Sustainability, vol. 12(24), 10691. DOI: https://doi.org/10.3390/su122410691

5. Real Change Starts With You. Raise Green. Available at: https://www.raisegreen.com/

6. Remove carbon as you grow your business. Stripe Climate. Available at: https://stripe.com/en-pl/climate

7. Renewable energy transactions are going digital. Blueyellow. Available at: https://www.blueyellow.com/

8. Smarter banking reverses global warming. Atmos Financial. Available at: https://www.joinatmos.com/

9. TreeCard. Available at: https://www.treecard.org/

10. Trine. Available at: https://trine.com/

11. Treelion beyond Gren. Available at: https://treelion.com/index_en.html

12. You can change Climate Change. Aspiration. Available at: https://www.aspiration.com/ 